\title{
Evaluation of New Zealand Electricity Generation Expansion in Meeting Dry Year Demands
}

\author{
Thahirah Syed Jalal, Student Member, IEEE, and Patrick S. Bodger
}

\begin{abstract}
After the commencement of the New Zealand Electricity Market (NZEM) in October 1996, generation expansion was made based on the wholesale electricity prices rather than through coordinated government planning. Since then, the installed generation capacity in New Zealand has been observed to follow a bust and boom pattern, resulting in energy shortages during dry winter years. A System Dynamics (SD) model has been developed to study the bust and boom trend. The model is then extended to evaluate whether the generation expansion proposed by the 2008 Statement of Opportunity (SOO2008) will be able to meet future dry winter year demands under the current market mechanism. The evaluation takes into account New Zealand's main storage lake cycles and the EI NiñoLa Niña Southern Oscillation (ENSO) phenomenon. The evaluation shows New Zealand is likely to face future energy shortages during dry years unless mitigation actions are taken.
\end{abstract}

Index Terms-Power generation planning, power generation availability, power generation reliability, power system simulation, reliability modeling

\section{NOMENCLATURE}

Carbon Capture Storage (CCS), Combined Cycle Gas Turbine (CCGT), Generation Expansion Model (GEM), Energy Capacity Margin (ECM), Electricity Commission (EC), Electricity Supply Industry (ESI), Electric Vehicle (EV), Integrated Gasification Combined Cycle (IGCC), Long Range Marginal Costs (LRMC), Market Development Scenario (MDS), Mixed Integer Programming (MIP), New Zealand Electricity Market (NZEM), Open Cycle Gas Turbine (OCGT), Statement of Opportunity (SOO), System Dynamics (SD)

\section{INTRODUCTION}

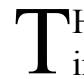
HE restructuring of the Electricity Supply Industry (ESI) in New Zealand has brought several changes to the way infrastructures are planned and expanded. After the commencement of the New Zealand Electricity Market (NZEM) in October 1996, generation expansion was made based on the wholesale electricity spot price in the energy market rather than through coordinated government planning.

After commencement of the NZEM, electricity shortages occurred in July 2001, March 2003 and March 2008. These

This work is done in the Electrical Power Engineering Centre (EPECentre), University of Canterbury, Christchurch, New Zealand. shortages raise questions as to whether the NZEM is sufficient to provide incentives for investors to build new power plants with adequate capacity and characteristics to meet the demand trends. It is suspected that the market structure has been the cause for the shortages as discussed in some literature $[1,2]$.

It has been shown in some studies [3-7] that deregulation of the ESI causes bust and boom cycles of generation capacity due to investment uncertainties. Initially, power generators are uncertain as to whether they should build a new power plant as that may affect the spot price in the power market and hence affect their profit returns. Then, substantial overbuilding occurs because most generators compete to build new power stations [8]. This bust and boom pattern has been observed to happen in the United States [3,5] and European countries [6, 7]. Fig. 1 shows that the installed generation in New Zealand declined for the first time in 1988 before steadily picking up again in 2000, despite the continuous growth of electricity demand within that duration [9].

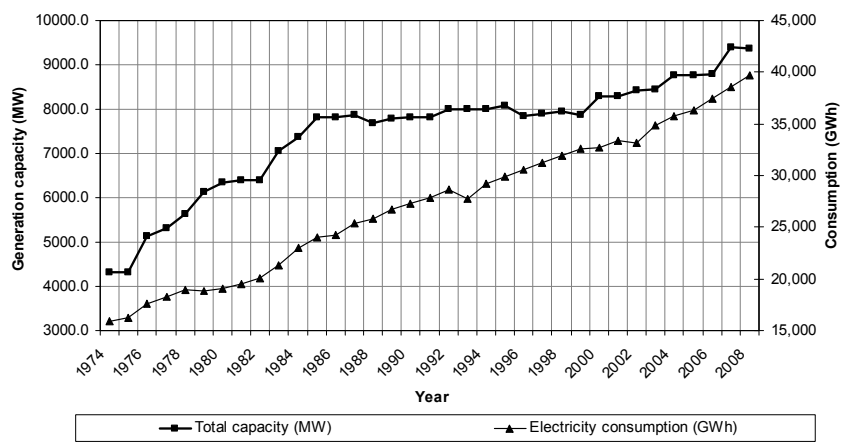

Fig. 1. Installed generation capacity in New Zealand from 1974-2008

New Zealand has been very good at harnessing its natural resources, especially its hydro potential for electricity. Hydro has remained the dominant electricity resource in New Zealand for many years. However, hydro storage here is relatively small compared to some other hydro dominated countries. The maximum storage available is only up to six weeks as compared to some Scandinavian countries which have up to two to three years of storage [10]. New Zealand is also made up of isolated islands and is far from neighbouring countries and hence cannot import electrical energy from other countries. For these reasons, the market is at the peril of weather patterns. Past dry winters have called for both conservation and high spot market prices [11]. Hence, in the analyses, the SD model takes seasonal hydro inflow variations 
and dry years into consideration under each scenario to identify if future energy shortages will occur.

\section{BACKGROUND AND OBJECTIVES}

Under part F of the Electricity Governance Rules 2003, the Statement of Opportunity (SOO) has been published periodically by the New Zealand Electricity Commission. The purpose of the SOO is "to enable the identification of potential opportunities for efficient management of the grid, including investment in upgrades and transmission alternatives" [12]. The Statement of Opportunity 2008 (SOO2008) considers five different future scenarios as elaborated in Table I. Under the various scenarios, the document provides electricity demand forecasts up to the year 2050 and tentative schedules of power plants up to the year 2040. However, the dry-year dispatch is not explicitly addressed in the document "as it is expected that market participants would effectively manage hydro storage using the capability of the grid to transfer power from North to South during periods of low demand" [12].

TABLE I

SOO2008 GENERATION AND DEMAND ASSUMPTIONS FOR FIVE DIFFERENT FUTURE SCENARIOS [12]

\begin{tabular}{|c|c|c|}
\hline Scenario & Generation assumptions & Demand assumptions \\
\hline $\begin{array}{l}\text { Sustainable } \\
\text { Path (MDS1) }\end{array}$ & $\begin{array}{l}\text { - High renewable energy } \\
\text { penetration backed by thermal } \\
\text { peakers } \\
\text { - New energy sources are } \\
\text { commissioned in the late } 2020 \text { s } \\
\text { and } 2030 \text { s }\end{array}$ & $\begin{array}{l}\text { - Active demand } \\
\text { side response to } \\
\text { manage peak demands } \\
\text { - Rapid electric } \\
\text { vehicle (EV) uptake } \\
\text { after } 2020\end{array}$ \\
\hline $\begin{array}{l}\text { South Island } \\
\text { Surplus } \\
\text { (MDS2) }\end{array}$ & $\begin{array}{l}\text { - Renewable development } \\
\text { proceeds at a moderate pace, with } \\
\text { all existing gas-fired power } \\
\text { stations remaining in operation } \\
\text { until after } 2030 \\
\text { - Wind and hydro generation } \\
\text { increase considerably, } \\
\text { supplemented by thermal peakers }\end{array}$ & $\begin{array}{l}\text { - The demand-side } \\
\text { remains relatively } \\
\text { uninvolved. }\end{array}$ \\
\hline $\begin{array}{l}\text { Medium } \\
\text { Renewables } \\
\text { (MDS3) }\end{array}$ & $\begin{array}{l}\text { - Geothermal is the main } \\
\text { resource, supplemented by } \\
\text { thermal plants } \\
\text { - Coal-fired units transition } \\
\text { through dry-year reserve to total } \\
\text { closure }\end{array}$ & $\begin{array}{l}\text { Aluminium smelter } \\
\text { is assumed to } \\
\text { decommission in the } \\
\text { mid-2020s. }\end{array}$ \\
\hline $\begin{array}{l}\text { Demand-side } \\
\text { Participation } \\
\text { (MDS4) }\end{array}$ & $\begin{array}{l}\text { - New coal- and lignite-fired } \\
\text { plants are constructed after } 2020 \\
\text { - Geothermal resources are } \\
\text { developed. } \\
\text { - Little new hydro can be } \\
\text { consented } \\
\text { - Gas-fired power stations } \\
\text { remains in full operation until } \\
2030\end{array}$ & $\begin{array}{l}\text { - Demand-side } \\
\text { participation becomes } \\
\text { important } \\
\text { - EV uptake is high, } \\
\text { and vehicle-to-grid } \\
\text { technology is used to } \\
\text { manage peaks and } \\
\text { provide ancillary } \\
\text { services. }\end{array}$ \\
\hline $\begin{array}{l}\text { High Gas } \\
\text { Discovery } \\
\text { (MDS5) }\end{array}$ & $\begin{array}{l}\text { - Major new indigenous gas } \\
\text { discoveries keep gas prices low to } \\
2030 \text { and beyond } \\
\text { - Some existing thermal power } \\
\text { stations are replaced by new, } \\
\text { more efficient gas-fired plants } \\
\text { - New CCGTs and gas-fired } \\
\text { peakers are built }\end{array}$ & $\begin{array}{l}\text { - The demand-side } \\
\text { remains relatively } \\
\text { uninvolved. }\end{array}$ \\
\hline
\end{tabular}

The SOO2008 uses a model known as the Generation Expansion Model (GEM) for its analyses. The model is formulated as a mixed integer programming (MIP) problem, written using the GAMS [13] optimisation software with a CPLEX solver. The model takes into account cost minimisation, future demand and HVDC link energy transfer between the North and South Islands in formulating the build schedules. However, the model does not include the effects of market supply and demand interaction in developing the schedules.

The authors have developed an SD model to study the electricity generation expansion issue in New Zealand and made projections to investigate whether capacity cycles will happen in the future. The results show that capacity cycles will continue to occur due to the current market structure. Comparisons of the resulting capacity cycles against the steady capacity growth shown in SOO2008 have been made $[14,15]$. The model is then extended to evaluate whether the cycles will cause energy shortages during future dry years. The analysis takes into account the nature of hydro resources in New Zealand.

\section{Evaluation Methods}

The model used in the evaluation is discussed in this section.

\section{A. Model features}

$\mathrm{SD}$ is a type of behavioural simulation model. It is a descriptive modelling method based on explicit recognition of feedback and time lags [16, 17]. Rather than model the electricity supply and demand using the concept of cause and effect, SD captures a more realistic dynamic relationship between them by incorporating feedbacks. The main interacting loops in the SD model are shown in Fig. 2. The components in the loops interact dynamically and influence each other's behaviour. The spot market price influences the investment decisions as what happens in the NZEM. The price is determined by the SD model from the difference between the supply and demand.

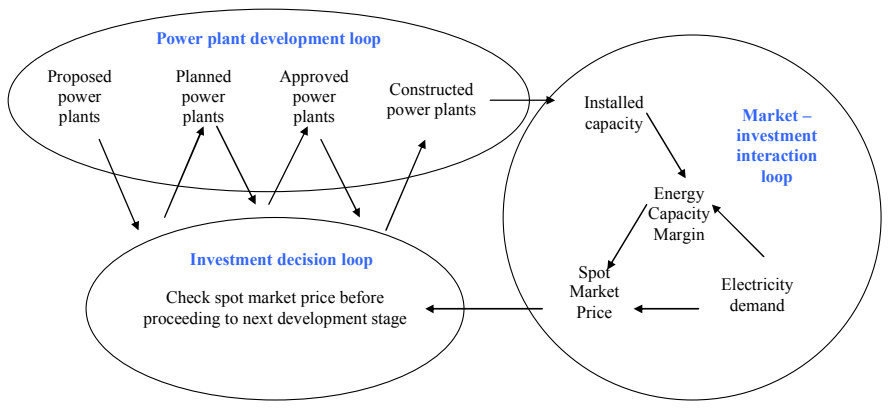

Fig. 2. The three main loops in the SD model that capture market interaction with power plant development

In the power plant development loop, before allowing the power plants to proceed into different development phases, their Long Range Marginal Cost (LRMC) is compared against the spot market price. They are allowed to proceed into the next development phase only if the spot market price is more than the plant's LRMC. This investment decision process is summarized in Fig. 3. 

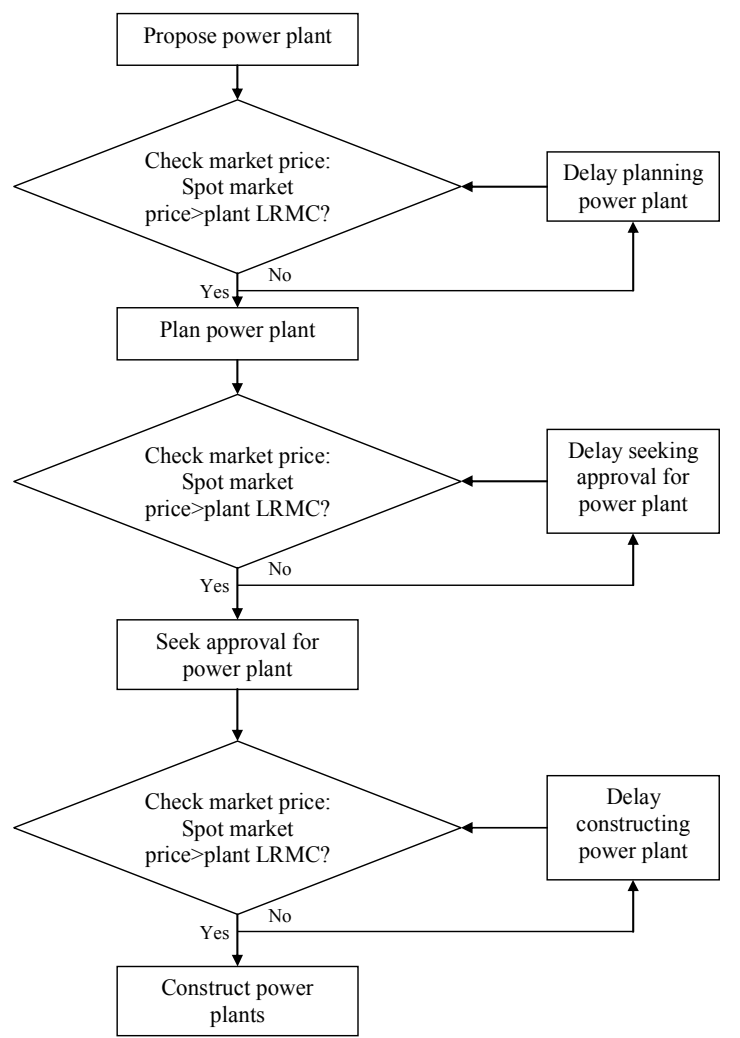

Fig. 3. Investment decisions based on the NZEM model

When a new capacity gets commissioned, the installed capacity increases. Depending on the gap between the supply and demand, the spot market price is adjusted accordingly. A big gap pushes down the price and vice versa. The adjusted price will then influence when a new plant comes in as it is only allowed to go through a development stage when its LRMC is exceeded by the price.

\section{B. Model inputs}

The SD simulations are run from 2010 until 2040, similar to the GEM model simulations for the SOO2008. To provide a fair comparison, the SD model uses the same inputs and assumptions as the GEM model for the SOO2008. These inputs are the demand forecast until 2050 (Fig. 4) under each scenario and the plants' LRMC and plant availability factors (Table II and III). Fig. 4 shows the annual total demand, but the model takes the data monthly to include seasonal demand variation. Electricity demand in New Zealand is typically higher in winter due to space heating. The tables show that the LRMC for thermal plants are higher due to higher gas prices and carbon tax. The LRMC values are applicable to New Zealand only as they depend on the available resources and technology here.

The model also uses the power plant schedules proposed by the SOO2008 as inputs to the power plant development loop. The scheduled plants are given a certain lead time and allocated different development phase durations depending on the plant type, as shown in Table IV.

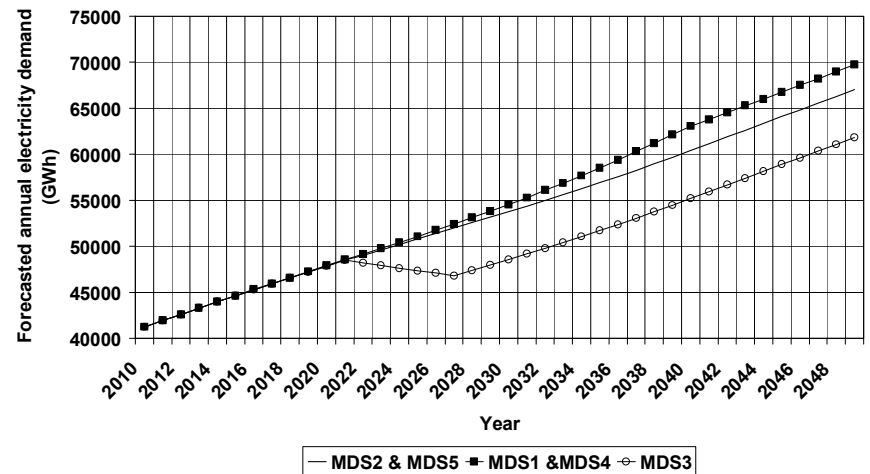

Fig. 4. Demand input data for the different projected scenarios [12]

TABLE II

LRMC AND Plant AVAILABILITY FACTORS FOR NON THERMAL Plants [12]

\begin{tabular}{|l|c|c|}
\hline \multicolumn{1}{|c|}{ Plant types } & $\begin{array}{c}\text { Plant } \\
\text { availability } \\
\text { factor }(\%)\end{array}$ & LRMC (\$/MWh) \\
\hline Hydro & 50 & 85 \\
\hline Geothermal & 90 & 80 \\
\hline Cogeneration & 70 & 130 \\
\hline Marine & 45 & 125 \\
\hline Wind & 45 & 80 \\
\hline
\end{tabular}

TABLE III

LRMC AND Plant Availability FaCtors for Thermal Plants [12]

\begin{tabular}{|c|c|c|c|}
\hline Plant types & $\begin{array}{c}\text { Plant } \\
\text { availability } \\
\text { factor }(\%)\end{array}$ & $\begin{array}{c}\text { LRMC } \\
\text { (\$/MWh) } \\
\text { - gas at } \\
\$ 7 / \text { GJ, no } \\
\text { carbon } \\
\text { charge }\end{array}$ & $\begin{array}{c}\text { LRMC } \\
\text { (\$/MWh) } \\
\text { - gas at } \\
\$ 10 / G J, \\
\text { carbon at } \\
\$ 30 / \text { tonne }\end{array}$ \\
\hline $\begin{array}{l}\text { Combined Cycle } \quad \text { Gas } \\
\text { Turbine (CCGT) }\end{array}$ & 90 & 75 & 107 \\
\hline $\begin{array}{l}\text { Open Cycle Gas Turbine } \\
\text { (OCGT) }\end{array}$ & 20 & 215 & 261 \\
\hline Coal & 90 & 85 & 111 \\
\hline 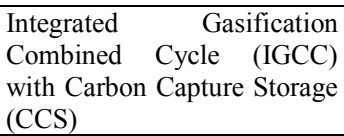 & 90 & 119 & 123 \\
\hline
\end{tabular}

TABLE IV

Plant Lead Time and Development Phase Duration

\begin{tabular}{|l|c|c|c|c|}
\hline Plant type & $\begin{array}{l}\text { Plant } \\
\text { lead time } \\
\text { (year) }\end{array}$ & $\begin{array}{l}\text { Planning } \\
\text { duration } \\
\text { (year) }\end{array}$ & $\begin{array}{l}\text { Approval } \\
\text { time } \\
\text { (year) }\end{array}$ & $\begin{array}{l}\text { Construction } \\
\text { duration } \\
\text { (year) }\end{array}$ \\
\hline Hydro & 5 & 1 & 1 & 3 \\
\hline Coal / IGCC & 4 & 1 & 1 & 2 \\
\hline CCGT & 3 & 0.5 & 0.5 & 2 \\
\hline OCGT & 2 & 0.5 & 0.5 & 1 \\
\hline Wind & 3 & 1 & 1 & 1 \\
\hline Geothermal & 3 & 1 & 1 & 1 \\
\hline Cogeneration & 3 & 1 & 1 & 1 \\
\hline
\end{tabular}

\section{Hydro Resource Considerations}

The hydro inflows in New Zealand are highly dependent on the season. The natural lake cycles cause high lake levels heading into summer (around December), reducing levels during summer and autumn and increasing levels during winter (around June) and spring [18]. Depending on the location, the inflows into storage lakes can also be affected by 
the El Niño-La Niña Southern Oscillation (ENSO). Monitoring of inflows to New Zealand's hydroelectric lakes stretches back to the 1920s. With the benefit of such a long time series, New Zealand's National Institute of Water and Atmospheric Research (NIWA) can show that the flow into South Island hydro lakes in La Niña years is considerably lower than the flow for other years [19]. The schemes in the South Island accounts for $66 \%$ of the total installed hydro capacity in New Zealand [20]. This is almost twice the capacity of hydro schemes in the North Island. Hence, drought in South Island lakes causes a serious problem for hydro resources in New Zealand.

From Fig. 5, it can be observed that severe La Niña happens at least once in every seven years [19]. The y-axis represents the Southern Oscillation Index (SOI) which indicates the severity of the ENSO. For La Niña, the higher the SOI, the worse is its severity. The figure also shows that energy shortages in New Zealand in 2001, 2003 and 2008 coincided with severe La Niña occurrences.

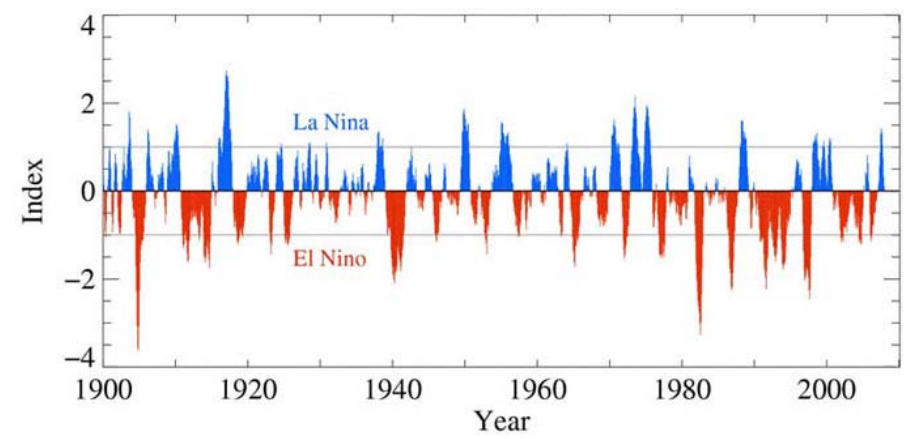

Fig. 5. Global ENSO occurrence in the last 110 years [19]

The GEM model used a constant plant availability factor for hydro plants. The SD model uses variable hydro plant availability factors for the different months of the year to take into account the lake level cycles (see Fig. 6). The monthly average values are calculated from past hydrological data of the main hydro lakes in New Zealand. To include the impact of a severe La Niña on the hydro resources, the SD model includes its effects once every seven years with dry winters occurring in 2015, 2022, 2029, 2036 and 2043. This hydro model has been validated using data from 1996 to 2008. The validation work will be published in other future publications. This model is deemed adequate since it is not the research objective to perform accurate forecasting of hydro data.

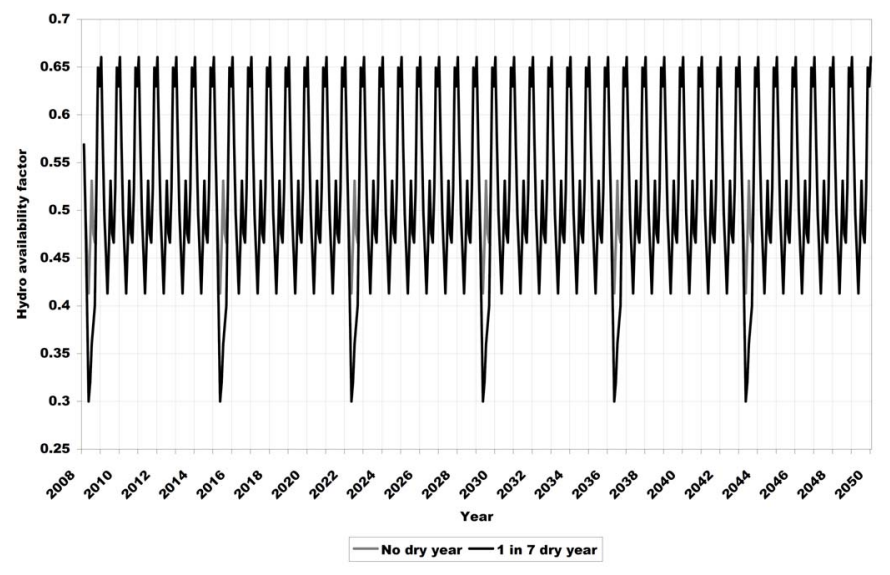

Fig. 6. Hydro availability factors used by the SD model

\section{Energy Shortages Evaluation}

In the last thirty years, New Zealand has been successful in meeting peak electricity demands (instantaneous power demand in MW) by having active demand side participation. However, the system has become energy constrained, especially during dry winter years where low hydro lake levels cause the supply to become insufficient to meet the energy demand (in GWh). To evaluate energy supply adequacy, a variable known as the energy capacity margin (ECM) is introduced. It is defined as:

$$
\mathrm{ECM}=\frac{\text { Available energy supply }- \text { Energy demand }}{\text { Energy demand }}
$$

ECM is a ratio and hence it is dimensionless or can be written as a percentage. The available energy supply is calculated from the installed capacity and the plant availability factor where:

Available energy supply $=$ Installed capacity $\mathrm{x}$ Plant availability factor

\section{(2)}

The energy demand is the load demand in GWh. The plant availability factors are shown in Tables II and III. The ECM is calculated on a monthly basis to take into account seasonal variations in electricity demand as winter consumptions in New Zealand are higher due to space heating.

\section{RESULTS AND CONCLUSIONS}

The following sections show the resultant installed capacities and ECM for the five scenarios. The installed capacities are compared with the scheduled capacities of the SOO2008. The ECM graphs show that the values change monthly with seasonal variation of hydro availability and demand. Since the SD model looks at the input demand data with a monthly resolution, lower ECMs are observed in winter when the demands are high due to space heating.

\section{A. Sustainable Path (MDS1)}

Fig. 7 shows that the SD model results lag behind the SOO2008 proposed schedule. This is due to investors waiting for the right spot market price before investing to allow for maximum profit. Capacity cycles are not obvious as the 
capacity dips are only for several months. The corresponding ECM (Fig. 8) become negative during every modelled dry winter, indicating the predicted occurrences of energy shortages.

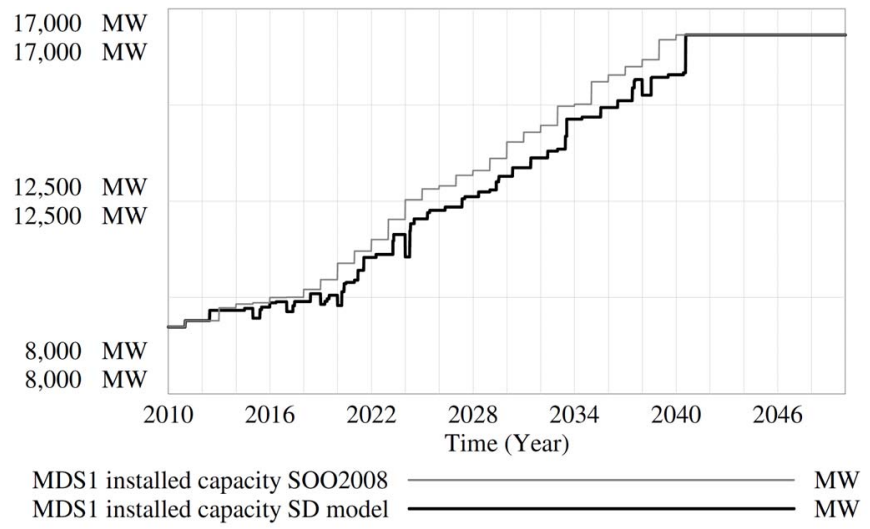

Fig. 7. Comparison of the SD model installed capacities with the SOO2008 for MDS1

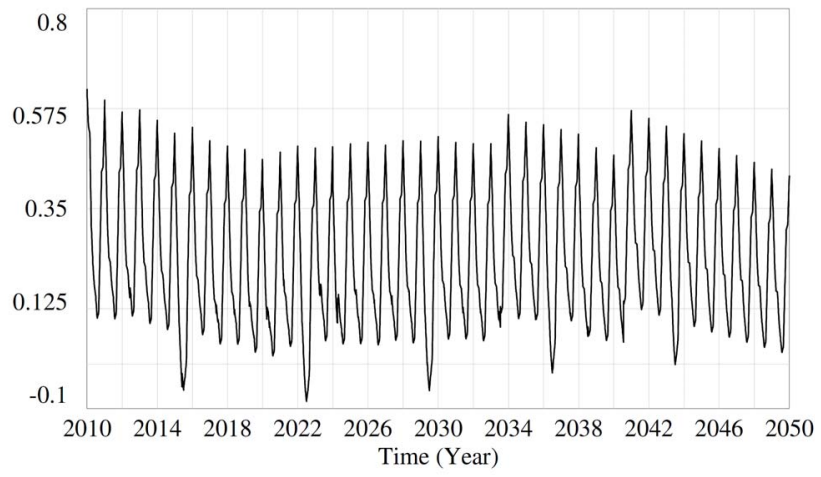

Fig. 8. Forecasted ECM for MDS1

\section{B. South Island Surplus (MDS2)}

Under MDS2, the differences between the SD model and the $\mathrm{SOO} 2008$ results widen throughout the years (Fig. 9). The gap between the two results for MDS2 is bigger than for MDS1 since the demand grows at a slower pace after 2022 (see Fig. 4). The corresponding ECM (Fig. 10) became negative during every modeled dry winter, indicating the predicted energy shortages.

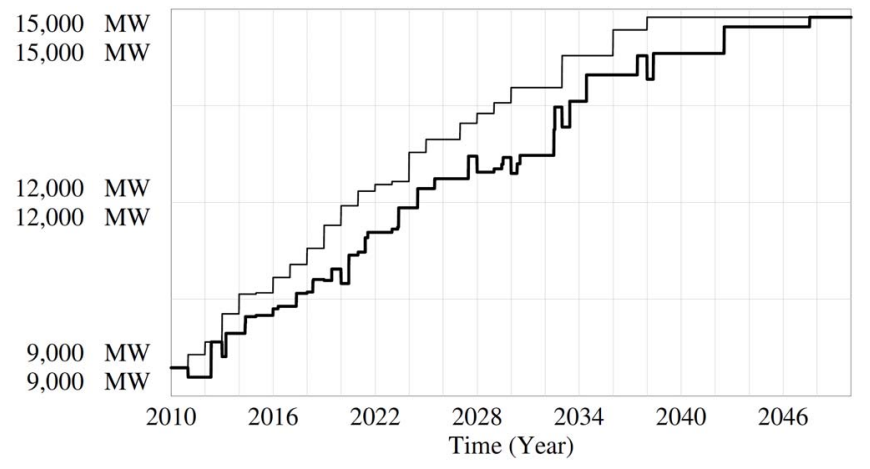

MDS2 installed capacity SOO2008 MW MDS2 installed capacity SD model

Fig. 9. Comparison of the SD model installed capacities with the SOO2008 for MDS2

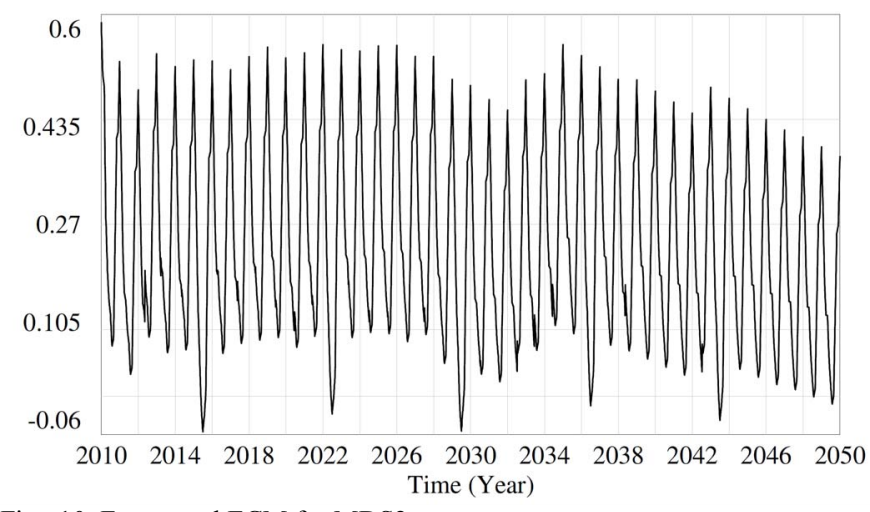

Fig. 10. Forecasted ECM for MDS2

\section{Medium Renewables (MDS3)}

The SD model predicts capacity cycles with a bust period of at least 6 years after 2026 (Fig. 11). This is because of the reduced demand due to the aluminum smelter being decommissioned after mid 2020 (see Table I and Fig. 4). The reduced demand makes the spot market price low and not conducive for new investment. The bust period results in a low ECM around 2031 (Fig. 12). A rapid boom follows afterward when investors try to maximize profits when the spot market price is encouraging again after a long period. The ECM is increased by the new capacities before it starts to decline again in 2041 .

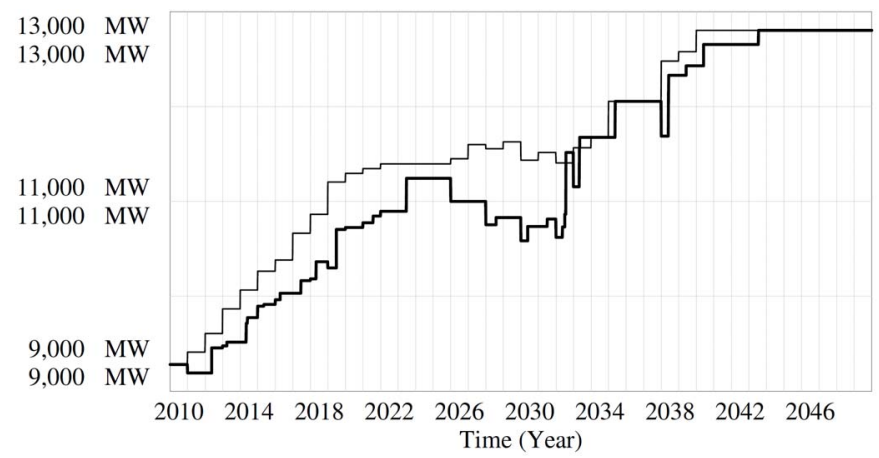

Fig. 11. Comparison of the SD model installed capacities with the SOO2008 for MDS3

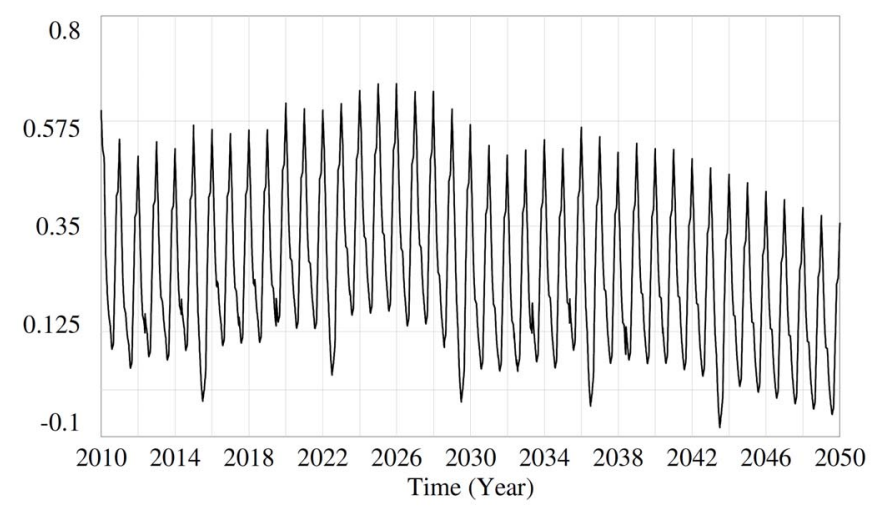

Fig. 12. Forecasted ECM for MDS3

\section{Demand-side Participation (MDS4)}

Under MDS4, the SD model predicts several cycles of boom and bust trends in the installed capacity (Fig. 13). The 
boom periods are in 2012-2022, 2030-2032 and 2035-2038 whereas the bust periods are in 2026-2028, 2032-2034 and 2038-2042. The booms after 2030 are steeper due to large capacity lignite and coal plants coming on line. The steady increase in demand causes the ECM to also become cyclic (Fig. 14). Shortages are predicted between 2015 and 2029.

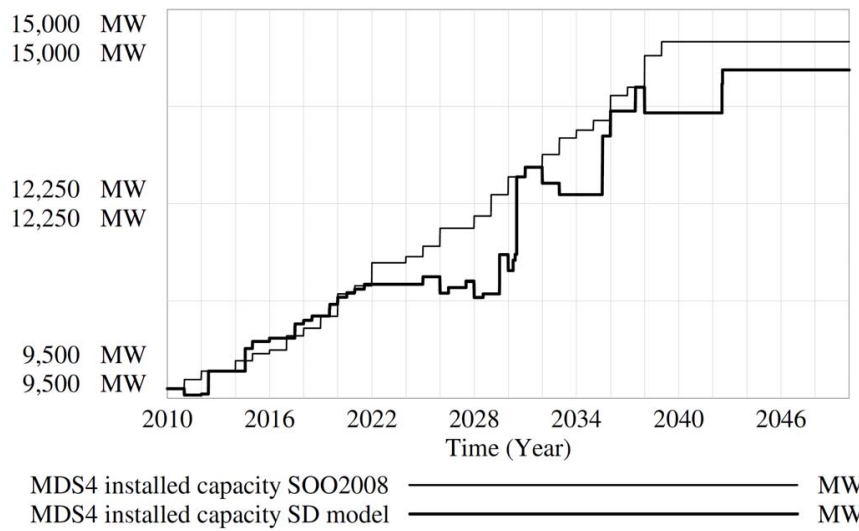

Fig. 13. Comparison of the SD model installed capacities with the SOO2008 for MDS4

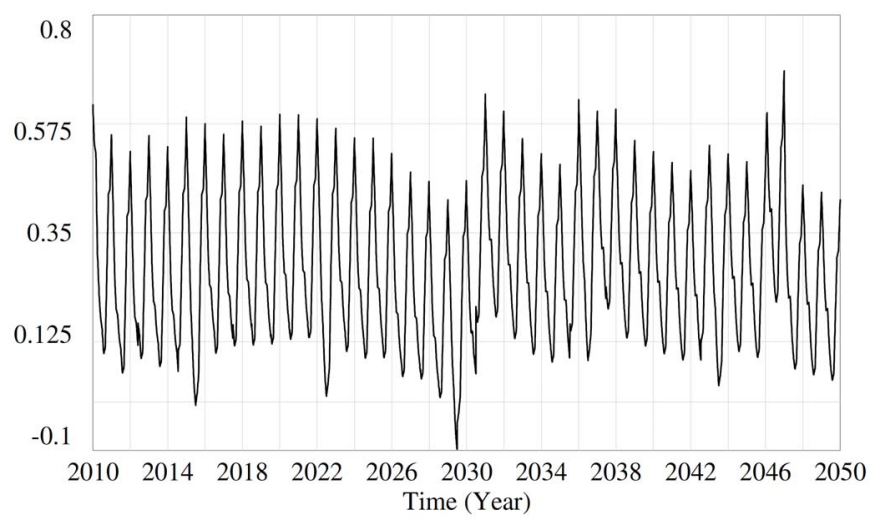

Fig. 14. Forecasted ECM for MDS4

\section{E. High Gas Recovery (MDS5)}

Under MDS5, a capacity dip is predicted in 2015. Since it coincides with a dry year, the ECM becomes very low for that year, indicating a severe shortage. The SD model results do not differ much from the SOO2008 results from 2016 up to the year 2028, as shown in Fig. 15. A large disparity is observed between 2028 and 2040. This is because most of the scheduled plants around that time are thermal plants of large capacity and high LRMC. Investors would wait longer for the right market condition before proceeding with the plants. Negative ECMs are observed every modelled dry winter years, as shown in Fig. 16.

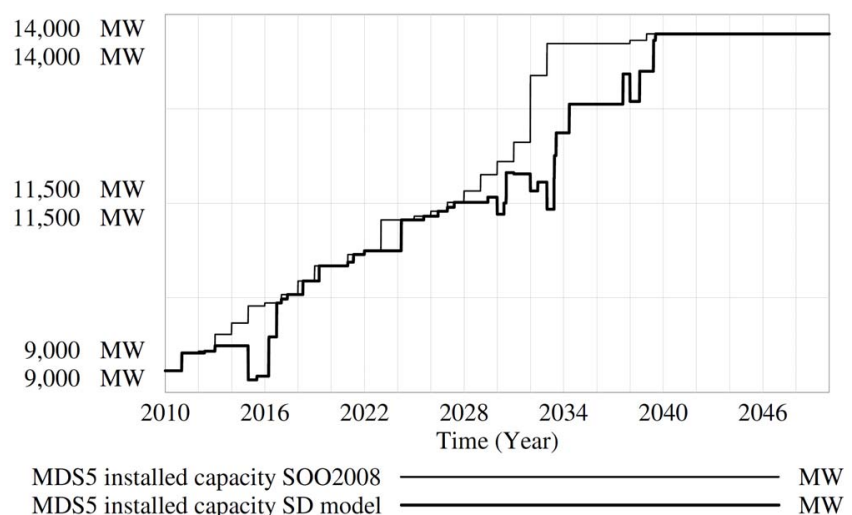

MDS5 installed capacity SD model

Fig. 15. Comparison of the SD model installed capacities with the SOO2008 for MDS5

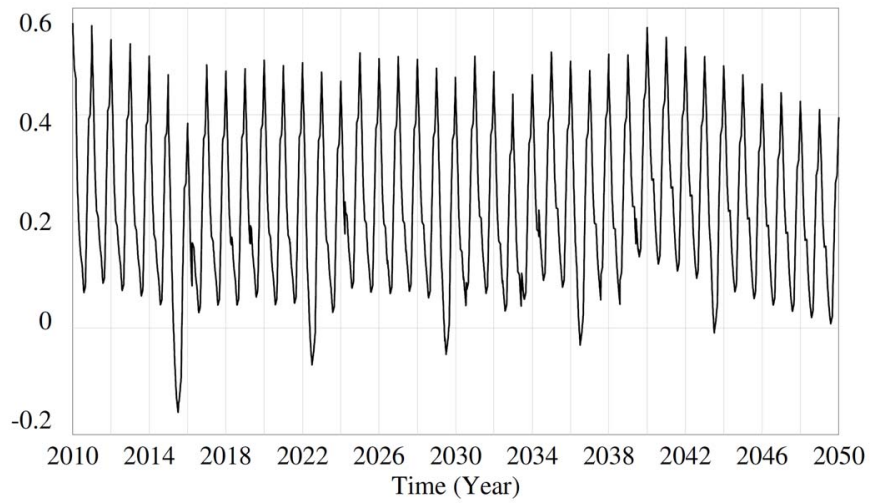

Fig. 16. Forecasted ECM for MDS5

\section{SUMMARY \& CONCLUSIONS}

Unlike the GEM model, the SD model is able to capture the effect of market interactions with generation investments. Investor's decisions to wait for profitable market conditions can thus be taken into account by the SD model. Therefore the SD model is capable of predicting future generation capacity cycles.

Boom and bust cycles have been observed in other commodity markets. However, the cycles in generation capacity are more pronounced because power plants are of large lumpy capacities, enormous capital investment and long lead time. It can be argued that capacity cycles are normal under a market environment to ensure that investments are made efficiently in meeting demands. However, a severe bust period in the generation capacity may cause severe electricity shortages that can be detrimental to the economy and cause inconvenience to consumers. In New Zealand, a bust period that is accompanied by a dry winter can cause a serious energy shortage (as predicted for the year 2015 under MDS5)

Comparing the results for the different scenarios, the cyclic patterns in installed capacities are more obvious when the plants are large capacity thermal plants with high LRMCs (MDS3 and MDS4). Having more small renewable plants (as in MDS1 and MDS2) produces less cyclic patterns as the LRMCs are lower and hence the profit can be recovered easily with relatively lower spot market prices.

The variable ECM provides a good indicator for measuring a potential electricity shortage. The resultant ECMs for all five scenarios are summarised in Table V. Comparing the ECMs 
for all five scenarios, dry winter shortages are identified for all scenarios. The least number of shortages are observed under MDS4. The severest shortage is predicted for the year 2015 under MDS5.

TABLE V

RESULTS SUMMARY

\begin{tabular}{|l|c|c|c|l|}
\hline \multirow{2}{*}{ Scenario } & \multicolumn{3}{|c|}{ ECM statistics (\%) } & Shortage occurs? \\
\cline { 2 - 4 } & Min & Max & Mean & \\
\hline $\begin{array}{l}\text { Sustainable Path } \\
\text { (MDS1) }\end{array}$ & -8.39 & 61.75 & 23.66 & $\begin{array}{l}\text { Yes in every } \\
\text { modelled dry winter }\end{array}$ \\
\hline $\begin{array}{l}\text { South Island } \\
\text { Surplus (MDS2) }\end{array}$ & -5.57 & 58.69 & 23.25 & $\begin{array}{l}\text { Yes in every } \\
\text { modelled dry } \\
\text { winter, after 2049 }\end{array}$ \\
\hline $\begin{array}{l}\text { Medium } \\
\text { Renewables } \\
\text { (MDS3) }\end{array}$ & -8.03 & 65.43 & 25.09 & $\begin{array}{l}\text { Yes in every } \\
\text { modelled dry } \\
\text { winter, after 2045 }\end{array}$ \\
\hline $\begin{array}{l}\text { Demand-side } \\
\text { Participation } \\
\text { (MDS4) }\end{array}$ & -9.78 & 68.43 & 27.38 & $\begin{array}{l}\text { Yes in 2015 and } \\
\text { 2029 }\end{array}$ \\
\hline $\begin{array}{l}\text { High Gas Recovery } \\
\text { (MDS5) }\end{array}$ & -15.84 & 57.06 & 22.71 & $\begin{array}{l}\text { Yes in every } \\
\text { modelled dry winter }\end{array}$ \\
\hline
\end{tabular}

The SD model results from the dry year analyses indicate the impact of generation mix onto New Zealand's energy security. High hydro penetration as in MDS1 and MDS2 can cause future energy shortages during dry years due to the high dependence upon hydro resources. However, under the current market structure, having more thermal plants aggravates the bust and boom patterns in the installed capacities. More severe shortages are observed if bust periods are accompanied with a dry winter year.

The SD model captures the dynamic interaction between different components in a power market, allowing for more realistic forecasts compared to other models. The developed SD model for New Zealand can identify any potential future shortages and provide opportunities for mitigation. However, under the lightly regulated market structure in New Zealand, investment decisions are left completely to the market participants. It is currently unclear how the regulator here can ensure that the installed capacities will be sufficient in preventing future dry years.

\section{REFERENCES}

[1] M. Bidwell and A. Henney, "Will the New Electricity Trading Arrangements Ensure Generation Adequacy?," The Electricity Journal, vol. 17, pp. 15-38, 2004/9// 2004.

[2] K. Neuhoff and L. De Vries, "Insufficient incentives for investment in electricity generations," Utilities Policy, vol. 12, pp. 253-267, 2004.

[3] A. Ford, "Cycles in competitive electricity markets: a simulation study of the western United States," Energy Policy, vol. 27, pp. 637-658, 1999.

[4] A. Ford, "Waiting for the boom: a simulation study of power plant construction in California," Energy Policy, vol. 29, pp. 847-869, 2001.

[5] T. Kadoya, T. Sasaki, S. Ihara, E. Larose, M. Sanford, A. K. Graham, C. A. Stephens, and C. K. Eubanks, "Utilizing System Dynamics Modeling to Examine Impact of Deregulation on Generation Capacity Growth," Proceedings of the IEEE, vol. 93, pp. 2060-2069, 2005.

[6] F. Lévêque, Competitive electricity markets and sustainability. Cheltenham, UK: Edward Elgar, 2006.

[7] D. W. Bunn and E. R. Larsen, "Sensitivity of reserve margin to factors influencing investment behaviour in the electricity market of England and Wales," Energy Policy, vol. 20, pp. 420-429, 1992.

[8] T. S. Jalal and P. Bodger, "The development of a system dynamics model for electricity generation expansion in New Zealand," in 2010
EEA Conference, Electricity Engineer's Association (EEA), Ed. New Zealand, Christchurch: Electricity Engineer's Association (EEA),, 2010.

[9] Ministry of Economic Development New Zealand, "New Zealand Energy Data File 2009," 2 July 2009 ed, 2009.

[10] Genesis Energy, "Electricity Trading in the New Zealand Electricity Market," 2010.

[11] Ministry of Economic Development New Zealand, "Chronology of New Zealand Electricity Reform," 2009.

[12] Electricity Commission, "2008 Statement of Opportunities," 2008.

[13] General Algebraic Modeling System (GAMS), "GAMS Homepage." vol. 2010, 2010.

[14] T. S. Jalal and P. Bodger, "The Development of a System Dynamics Model to Evaluate Electricity Generation Expansion in New Zealand," in 20th Australasian Universities Power Engineering Conference (AUPEC 2010) Christchurch, New Zealand, 2010.

[15] T. S. Jalal and P. Bodger, "Evaluating the Impacts of Generation Capacity Cycles in New Zealand," in 2011 IEEE PES Power Systems Conference \& Exhibition (PSCE) Phoenix, Arizona, United States: IEEE, 2011.

[16] J. W. Forrester, Industrial dynamics. [Cambridge, Mass.]: M.I.T. Press, 1961.

[17] J. Sterman, Business dynamics : systems thinking and modeling for a complex world. Boston: Irwin/McGraw-Hill, 2000.

[18] Opus International Consultants Limited, "Lake Level History," E. Commission, Ed., 2009.

[19] National Institute of Water and Atmostpheric Research, "Low hydro inflows: it's La Nina " National institute of Water and Atmostpheric Research,2008.

[20] Electricity Commission, "Generating Power Station List October 2009." vol. 2010,2010

\section{BIOGRAPHIES}

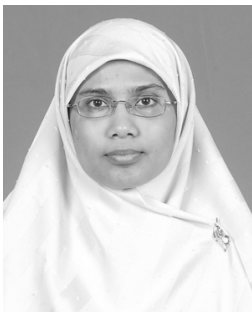

Thahirah Syed Jalal completed an MEng. in Engineering Science from Oxford University, United Kingdom in June 2002, under a scholarship from the main power utility company in Malaysia, Tenaga Nasional Berhad (TNB). She worked in TNB's wholly owned university, Universiti Tenaga Nasional (UNITEN) from July 2002 as a lecturer. Her research and consultancy work there was mainly on electromagnetic fields and sustainable energy. She then pursued her PhD at University of Canterbury, New Zealand. Her thesis is on the development of a System Dynamics (SD) model for generation expansion in New Zealand. Upon completion of the PhD in 2011, she joins Unison Networks Limited, New Zealand as a Network Investment Specialist.

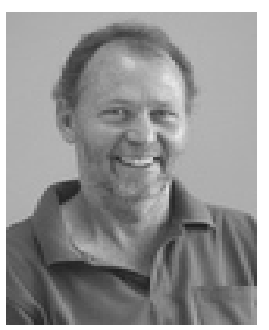

Pat Bodger has BE (Hons) (1972) and PhD (1977) degrees from the University of Canterbury. He has 5 years experience as a design and construction, power station maintenance and commercial engineer with the New Zealand Electricity department. He joined the University of Canterbury, Christchurch, New Zealand in 1982 where he is Chair of Electric Power Engineering and a Director of the Electric Power Engineering Centre (EPECentre) 